\title{
The contemporary cosmopolitan condition: borders and world literature
}

Who is today the worldly subject of a cosmopolitan experience? Is there a role for world literature as a field of inquiry into the role of literature in globality to provide an account of this experience? In response to the invitation to participate in the discussion of the current critical agenda of cosmopolitanism - as a framework that could sustain and reaffirm the potential of narrative imaginaries of transnational subjectivities, whose sensibility is informed by multiple and overlapping commitments and loyalties, to transcend cultural differences and produce a concept of common humanity - I originally presented a reflection on the power of certain images and their contemporary on-line ubiquitous modes of circulation and reproduction to provide us with a world picture, and thus with a momentarily discerning worldview. I will take here that presentation as a point of departure to expand on two ideas, the premise that in any particular case, cosmopolitanism's value needs to named, demonstrated and argued for and that contemporary literature and visual culture can be the vehicle for a cosmopolitan perspective that organizes the world in a more self-implicated and ethically fair way. This last point takes me into an analysis of American writer and photographer Teju Cole's “A piece of the wall”, a literary and visual essay originally published on-line on his Twitter platform with his photographs in $2014 .^{1}$

My presentation at the symposium focused on analyzing the case of the photograph of Alan Kurdi, the three-year old Syrian boy of Kurdish origins who drowned in the Mediterranean Sea in 2015 while fleeing with family and trying to reach the coast of Greece from Turkey. His lifeless curled-up body resting on the shore was photographed by the Turkish photographer Nilüfer Demir and the image went viral and generated worldwide reaction. International responses emerged almost immediately. This image became a symbol of the worldwide child refugee crisis, of Syrian refugees' plight; it called on Europe's tepid response, the background story uncovered weeks after brought debates on

1 "A piece of the wall" was later published as the closing essay in Known and Strange Things (Cole 2016: 363-376) and one of the photographs taken by him on site in Sasabe (2011), at the US-Mexico border was reproduced in it, and later published and accompanied by a new text in his Blind Spot (2017). The essay can be read in its original format at <https://twitter.com/teju cole/timelines/444262126954110977?lang=en>.

Ә Open Access. (C) 2019 Alejandra Uslenghi, published by De Gruyter. (c) BY-NC-ND This work is licensed under a Creative Commons Attribution-NonCommercial-NoDerivatives 4.0 License.

https://doi.org/10.1515/9783110641134-014 
international law and procedures to grant or deny asylum; and the image was a center of attention in that year's Canadian elections. My point was not to illustrate the contemporary "cosmopolitan" condition, now abjectly visible as the traumatic, forced, expulsive experience of detachment from national belonging and identity into the bared in-between, marginal, socially undesirable yet economically useful, opened to unlimited exploitation and violence. That would have contributed to a current overuse and devaluation of this concept, sometimes too easily applied as a characteristic and possession of people that have seen "cosmopolitanism" thrust upon them by traumatic histories of war, dislocation and dispossession. ${ }^{2}$ I will come back to this point, but instead my analysis tried to illuminate the conditions of possibility that allowed for both that brief instance of world community consciousness and empathic moment, when violence and death, the conditions of bare life inscribed upon a child's body reminded us that there is a world, a space of shared co-habitation, being undone. Briefly, those conditions of possibility had to do with the technological infrastructure of reproduction and distribution of images at and unprecedented speed that connected almost instantaneously a local event, its visual record with a worldwide audience through multiple platforms, activating multiple frameworks that produced interpretations and readings of that image capable of evoking photojournalism' history of testimonial truthful accounts, aesthetic dimensions of suffering - centuries of pictures of wounded, suffering and dead bodies could be condensed in that small lifeless lying body - and a universalist human rights discourse that rightly identifies children as the most vulnerable and defenseless population in today's perpetual war context. ${ }^{3}$ These images of distance suffering impose an ethical demand on viewers, compelling us to negotiate our own proximity and these, even if brief, acts of recognition of suffering break, interrupt the grand narratives of the normative subject. ${ }^{4}$ The consciousness of media globalized events, I argued, shows that cosmopolitism and its

2 As Pnina Werbner states, "At the present cosmopolitan moment in anthropology there is a temptation to label almost anyone - African labour migrants, urbanites, Pentecostals, traders, diasporics - 'cosmopolitans”' (2018: 17). Bruce Robbins writes, "If some people these days tend to feel a certain sinking of the heart when the word cosmopolitanism is pronounced, or at least a diminishment of intellectual expectation and excitement, I think it is only partly because the word is now being overused" (Robbins/Horta 2017: 41).

3 As Bruce Robbins states, “today's cosmopolitanism is asking for a great deal more than it can expect to get: namely, an end to war making. For Kant and for a majority of its champions since, peace has been cosmopolitanism's primary aim and measure" (Robbins/Horta 2017: 41). 4 Judith Butler's reflections on ethical demand and recognition of suffering in her "Torture and the Ethics of Photography" (2008) are essential to my argument, she analyzes the case of the photographic material of Abu Ghraib. 
knowing-how-to-be in the world, like global mobility, is marked by multiple inequalities, and that its definition is an object of dispute (Whose cosmopolitanism? Which cosmopolitanism?). My obvious emphasis on a visual culture phenomenon brought the discussion with literary scholars to bear on the question of narrative, fiction, and contemporary literature's capacity for such impact and the old cosmopolitan idea that the cultivation of the humanities is the affective and educational foundation for an empathic cosmopolitan ethical subjectivity, emancipated from any assigned identity, beyond one's mother tongue and open to the recognition of the "other-subject". My purpose here is not to fall back into ethics, but to expand on this inquiry that searches for a literary experience and a literary form, which does include or experiments with the visual correlation, that could respond to this demand and from what kind of perspective is it possible to narrate or enunciate such experience. Is there a possibility that the perception of a mediatized event, which "unites" us on a global scale, even just briefly, and this "consciousness" corresponds to any real shared experience?

\section{Cosmopolitanism at the border}

Cosmopolitanism as a critical agenda in the humanities has been distinct from all identity-based beliefs in human indigeneity, ancient and contemporary, and particular forms of nationalisms countered by its association with ethical universals. Globalization as a transformative economic and social scenario with its figurative tropes of "global village", interconnected society and its virtual aspects, and the configuration of a global class of international experts, technocrats, business leaders and advisers, image creators who move rapidly, fluidly, freely relying on technological advances and embodying the grand narrative of a "world without borders" demanded an actualization of its critical potential. Thus, since the 1990s cosmopolitanism has also been the arena where the meaning and the comparative advantages of multiculturalism, and on conflicts of universalisms and the negotiations of the value of alterity has taken place (Hollinger 2001). The shift from an "old" cosmopolitanism, understood as a normative abstraction, in the singular - the commitment with the welfare of humanity as a whole - but enunciated from the point of view of the humanist capable of standing above cultural particularities and with the power of the privileged who speaks for all humanity, has given way to a "new" cosmopolitanism. This new cosmopolitanism, an empirical, plural and descriptive rather than normative cosmopolitanism, draws "from below" - a contrast perhaps more readily embodied by the perspectives of Martha Nussbaum (1997) and Anthony Appiah (2006) - delving into the dislocated experiences of a set of the 
new, less privileged cast of cosmopolitan characters and their singular cosmopolitan viewpoints. This shift emerged from a larger critique of cosmopolitanism discourse as elitist western liberalism, identified with high-minded humanitarian disinterestedness, and always complicit with imperial conquest. In the words of David Harvey, it could turn into "an ethical mask for hegemonic neoliberal practices of class domination and financial militaristic imperialism" (2009: 84) or in Timothy Brennan's “[...] the essence of cosmopolitanism in a single formula, it would be this. It is a discourse of the universal that is inherently local - a locality that is always surreptitiously imperial” (1997: 81).

This fundamental transformation was accompanied by research into new archives and at a different scale, and a plethora of new adjectives came to qualify this approached from below: rooted cosmopolitanism, vernacular, subaltern, banal, and more recently Afropolistanism. ${ }^{5}$ From a cosmopolitanism perceived as a badge of elitism, embodied by scientific travelers, western anthropologists, agents of the empire, elite intellectuals and translators, to a pluralized cosmopolitanism that explored the perspectives of native informants, sidekicks, guides, migrant laborers whose race, class, gender often left them on the margins of the "autonomous travelers". Thus, cultural exchanges that subvert metropolitan-peripheral dynamics emerged and came to redefine the cosmopolitan condition in terms of particular historical experiences. In this context, cultural cosmopolitanism and the politics of cosmopolitanism acquired a positive valence and progressive implications. This new cosmopolitan discourse has sought to describe the cosmopolitan condition in a sense of a lived experience, an experience of sharing the world with cultural as well as political implications, rather than an ideal, a political category or analytic concept. In this sense, it complicates the assumption - a rather idealistic one that has been co-opted by neoliberal discourse - that cosmopolitan people are those "able to feel at home anywhere”, constantly roaming the world, never uncomfortable. The cosmopolitan experience I am interested in analyzing is unsettling in its confrontation of difference, requiring introspection and negotiation. As Thomas Bender has reflected, “[o]ne’s engagement with difference, whether marked by pain or any other condition of difference, provides an experience that prompts both reaching out and a self-reflexive awareness” (Robbins/Horta 2017: 121). This is precisely the way in which the discourse of cosmopolitanism is defined

5 In the Latin American field, Mariano Siskind (2014); Héctor Hoyos (2016); Ignacio Sánchez Prado (2018) have produced studies taking up these interrogations and contributed Latin American voices to the scholarship on cosmopolitanism and world literature. The critical anthologies edited by Gesine Müller (2015) and Juan de Castro (2017) have further contributed to expand the scope of the debate. 
as lived relation to difference, or as Judith Butler has named it, the idea of cohabitation, of having a common world, which for Hannah Arendt constitutes the basic condition for politics (Butler 2012: 134-151).

There is perhaps today no more contested site to test this decentered kind of experience that of the border and border crossing. As many critics have pointed out, the imaginaries of globalization have not made borders disappear, regardless of certain habits of cosmopolitan consumption; much to the contrary they have proliferated. ${ }^{6}$ Globalization has multiplied borders as the means of mobility have spread across the planet and it has fragmented and disassociated some borders from others, where economic activity, trade and consumption, no longer shares the same boundaries as communications or political actions. Thus, making ubiquitous our experience of crossing them, a shared experience where cosmopolitan life is configured and where the concreteness, rudeness and brutality of the contemporary world is experienced. A global culture as a culture of borders, a wider and more pragmatic kind of cosmopolitan experience that we are learning to live and traversed. Each border situation - "thresholds, dead and transitional times, places of encounter, crossing and conflict, relationships that require unprecedented translations and exchanges" as Michel Agier has analyzed them (2016: 156) - is where the contemporary cosmopolitan condition is being formed as it ritualizes the relationship to the other. Agier further argues on the new centrality of the border to contemporary cosmopolitan experience:

In a global and hybrid world, where experiences of the unfamiliar and of uncertainty is practically everyday, this condition is born on the border, that is, in everything that makes for the border. This includes uncertain places, uncertain times, uncertain identities that are ambiguous, incomplete or optional, indeterminate or in-between situations, uncertain relationships. These are border landscapes, in which encounters and experiences bring into relation a here and an elsewhere, a same and an other, a 'local' fact and a 'global' context (simply meaning someone or something that comes from 'outside'). (Agier 2016: 8)

It is by what happens at those border sites that we learn the ways of the world; the border, always closer than we believe and far from the exotic detour into distant countries that we may imagine as radically other, is where the othersubject is found. In order to recognize his or her existence, it is necessary "to extract oneself from identity-based beliefs and utopias that separate an

6 Wendy Brown (2014) reflects insightfully on a "desire for walls", the sentiments, emotions, fantasies attached to the figure of the alien, of protection, of insulation, and of purity that engender social fears upon which political discourse act. 
absolute and intrinsic 'within' symbolically and materially walled in, from an 'outside' that is nameless and voiceless, generating more fear in that is reduced to silence and dismissed” (Agier 2016: 9). In this act of recognition, as Julia Kristeva has analyzed, each person is also invited to discover their relative foreignness in the gaze of others, others with whom we share the same borderlands: "To discover our disturbing otherness, for that indeed is what bursts in to confront that 'demon,' that threat, that apprehension, generated by the projective apparition of the other at the heart of what we persist in maintaining as a proper, solid, 'us'” (Kristeva 1991: 192). From this experience each takes a certain distance from their own construed identity by engaging in a cultural work that provides an understanding of the place in which we live and others whom we live with. It is this cultural work and a certain understanding of the "global" what I would like to highlight in Teju Cole’s 2014 essay. ${ }^{7}$

\section{"A Piece of the Wall"}

On March 13, 2014 the American writer Teju Cole published his non-fiction essay on his first-hand experience at the US-Mexican border, "A Piece of the Wall”, entirely on his Twitter account. The essay comes from a residency in Arizona, where Cole researched, photographed and wrote about the border culture, the locals and migrants experience. It comprised approximately 250 tweets over the span of a few hours, which combined his direct posts with his either first person or third person narrative text with eight intercalated photographs Twitter allowed then to post 140 characters of text but also single images - and he adapted dialogue to that format opening and controlling 12 different accounts, one per each character whose testimony he included. Each person was given their own avatar either with photos he had taken of them or symbols or logos connected to their work. It is telling that he characterized this use of the device and platform to enact a multiplicity of voices on the issue of immigration and border culture, "a bit of world-building” (Calvin 2014). The limit of words in the Twitter format required him to adapt some of his sentences, breaking some longer text and strengthening some fragmentary ones. The essay reached a wide audience; through links, forwarded messages, and other social network platforms it was further reproduced and it is still possible today to read it in its

7 The scholarship on US/Mexico border and its rich and complex literary tradition is vast, here I am pointing out the experience of multiple forms of strangeness that overlap in Cole's writing on this site and highlighting a distanced mode of relationality. 
original format as well as in print. Cole was interviewed via email by multiple sites, in blogs, and literary online platforms. Many readers were caught up in the experimental use of the social platform - something that Cole had done before inviting collaborative storytelling and photo submissions through his accounts - but as he himself stated, his motivation were less a writerly experiment at blurring the boundaries of fiction and non-fiction usually rendered in the language of neoliberalism as "innovation", but a test of the resonance of his writing within the framework of that global platform, immersing it in the digital media, letting it run loose through the internet and seeing who could be reached. A narrative of the conditions at the border that sought to break through the virtual cultural borders. A test of the virtual public sphere, checking the expanse and boundaries of what we could call a "global audience" and the possibility of an "instantaneous" audience. Also, a test of the idea that a serious and rigorous piece of writing should not be restricted to the print format, which speaks of a different medium, one which has always been considered until now perhaps hegemonic, as well as a claiming a different temporality. As he stated in an interview, behind that appeal to a global audience there was also a call for empathy that his account of border experience wanted to convey: "I'm not getting my hopes up, but the point of writing about these things, and hoping they reach a big audience, has nothing to do with 'innovation' or with 'writing.' It's about the hope that more and more people will have their conscience moved about the plight of other human beings. . . I continue to believe the emperor has a soul" (Calvin 2014). The act of witnessing - he attends a hearing in a courtroom where chained migrant workers are charged with illegal entry - gives way to the contemplation of the rough, arid, labyrinthine forms of the desert landscape, "The land is a maze. You have to be guided through, right from the beginning you had to be guided. The first story in the world is about safe passage" (Cole 2016: 367). The conversations with the locals - the waitress, the taxi driver, the border patrol officer, the chief medical examiner, the city arts council official, the migrant's advocates, in front of whom he is both stranger but a national, the bearer of passport documents that allow him crossing - weaved a complex narrative that provides us insight into the temporal, social, and spatial dimensions of the border experience. Its local inscription of individual and collective lives; its territorial transformations and the materialization of an inside and an outside; and the relational framework represented by the border itself, representing both a division and the placing in relationship constitutes in Cole's essay a regard of the border not as fixed and ahistorical given but a study of the border as it is being made, contested and reinforced exposing the displacements that have preceded that very emplacement. As the taxi driver tells him: "We didn't cross the border. The border 
crossed us. We've always been here. This business of trying to keep people out: in the end it's futile" (Cole 2016: 373). The layers of stories that Cole collects locally as well as his photographs show us how those "already here" when others arrive, transform themselves into the "always here", claiming an identity of space that is always the result of one's production of one's space, instituting locality and belonging.

Re-sensitizing the de-sensitized virtual global sphere becomes then possible with a narrative that portrays the border from the writer's own cosmopolitan experience - as he tells us, Teju Cole was born in the US to Nigerian parents, grew up in Lagos, and returned to the US for pursue his college education - he writes, "Citizenship is an act of imagination. I was born American, but I also had to learn to become American” (Cole 2016: 374), one deeply embedded into racial history, "my understanding of American experience has mostly been from the point of view of a recent African immigrant. I tried to understand the interconnected networks of trade and atrocities that formed the histories of the cities I've known and visited... In Tucson, witnessing the ongoing crisis in the borderlands, I have to revise my understanding of my country to include this, too" (Cole 2016: 374). In "A Piece of the Wall" the border is thus the site of interpellation of one's own sense of self and the cosmopolitan subjectivity Cole examines is the one that cultivates both commitment and distance, one's own possible distance of the self, always worked by identity assignments, and an awareness of the possibility of dialogical knowledge of the others. The border is the site of awareness of the porosity of the here and there, the traces of the elsewhere in the here and vice versa, which relativizes those primary roots and given affiliations. ${ }^{8}$ Like the Twitter accounts Cole activated to give voice to those he interviewed, the dialogical knowledge of others permeates the essay and portrays that sense of liminality which is not just personal but also reveals the social dimension of the border, people situated in a space of uncertainty about social existence and being recognized by others.

Among the images he also published we can see scenes from the border towns of Nogales and Sasabe south of Tucson in Arizona depicting the precarious infrastructure of "puestos fronterizos", border checkpoints, as well as migrant assistance NGOs, where the sense of transience contrasts with the

\footnotetext{
8 Cole's published fiction - in particular his novel Open City (2011) - has been deemed either "an exemplary cosmopolitan performance", one in which the global Anglophone novel instantiates ethical connections across national identities, or critical of this program and his storytelling as not invested in forging international contact zones but in cautioning against a facile instrumentalism equating cross-cultural connection with social transformation. See Vermeulen (2013) and Saint (2018).
} 
border-long extension and the background imposing presence of the desert landscape. Fences, barbed wire, natural and built dividers traverse the towns. These images, taken by Cole while traveling there, underline certain points of the narrative and as in many photographs by the author, oscillate between close attention to detail and a kind of panoramic detachment. Thus, the gaze also negotiates its own liminality, getting closer and distancing, a street style photography that defines Cole's approach to the media (see Lucas 2017). The portrait of Isabel García, the leader of the Coalición de Derechos Humanos and public defender in the Pima County - taken in her office amidst her daily work fighting inhumane treatment of migrants and gathering information to help with identification of dead bodies found in the desert or for families in search of loved ones who have never returned - shows her in a stoic, serene but stern profile, her face turned to the side. While she looks away from the camera, the narrative focuses on the arduous process of identification of unknown bodies, the collection of body marks, details, physical peculiarities, all that can be used to scan the remains, the remnants of those lives now scattered through the desert. In the words of Kat Rodriguez, another leader, the coexistence with this reality demands a certain emotionless impassiveness: "People have to be desensitized", says Kat, "to allow the kind of horrible death that happened to someone like René. If you really confronted it, it would be unbearable" (Cole 2016: 371). The image we confront next as Cole forces us to bear the sight is a close up of the morgue unit of Pima County where "rows of body bags in metal shelving, stacked in regular array like a card catalogue, five levels high" (Cole 2016: 375). Once again the weaving of narrative and photography to re-sensitize the reader, catch the distracted attention of the Twitter audience, and confront them with the harshest of visual testimony.

The visual trace of this biopolitical control exercised at the border on the bodies of migrants to control the "flows" of populations is clearly rendered in the two photographs where Cole depicts the wall. The red corrugated wall near the US-Mexico border in the town of Sasabe stretches through scrubland in the background, cutting through the landscape towards the horizon line as it reaches a blue and cloudy sky. This red wall, which also draws a bloody red line, can be seen through a screen of wire fence bisecting the frame, an angular geometry that reproduces the border lines colliding and signaling the here and there and the spatial dimension of the border, the boundary that partitions the space and materializes an inside and outside. The photograph does not depict any human figures, but the space of contact and exchange between the two edges, the two sides is a graveyard of unknowns, "In the grass near the inspection post, on the Mexican side, someone has planted two white crosses. 
The large one lists at a forty-five-degree angle. On the smaller, I can make out the word 'mujeres"' (Cole 2016: 369). The border is also a cemetery, a site of mourning for voiceless, silenced bodies where the visual testimony, the mark of those crosses in the ground, becomes a path of remembrance in face of the impossibility of naming them and resisting the biopolitical model of alterity, the power of life and death exercised to its limits, by "letting die" the undesirable, the foreigner, the outsider.

The contemporary cosmopolitan experience of the border raises the signification of questions that come to define our critical agenda today: there is no common world without alterity, and the relationship to the others is imperative to the construction and functioning of a common world. Any genuine common world necessitates a personal and societal shift in the treatment of marginalized people, if it will not just be a graveyard. As Michel Agier writes on the critical potential of cosmopolitan thought,

The question then is to transform the global foreigner, invisible and phantom-like, whom identity politics leaves nameless and voiceless behind material or invisible walls, bureaucratic or ideological, into a person whose alterity becomes again relative and potentially closer. On this basis it will be possible to reconsider each border as a new test of alterity where an other-subject emerges, the cosmopolitan subject, come to disturb the existing identity-based order. (Agier 2016: 156)

The transformation rests on these kind of narratives and images, which do not renounce an ethical call but at the same time establish a point of encounter in the common platforms of the global virtual village, seeking to interrupt the incessant flows of daily communication, claiming the attention of that global audience to incite an emotional and aesthetic response. The title of the essay refers to the last image Teju Cole included in his posts, it depicts a piece of corroded, rusty metal bar with blueish tones, laying on top the writer's wooden table, "On the table on which I write this is the piece of iron I took from the base of the wall at Nogales more than two years ago. The officers at Tucson Airport gave me trouble (it was in my hand luggage, and came up strange and solid on the X-rays). I told them it was a memento. They took it out of the bag and examined it, puzzled. Then they let me go, with my piece of the wall" (Cole 2016: 376). An image and an object of remembrance that brings the border experience home, closer, accessible and comprehensible. The border is not a distance elsewhere, it is actually here, in a contemporaneity and spatial continuity of the world that makes it possible to live alongside others. The wooden table and the iron bar, the material objects out of which a common world, the world in common, can be imagined. 


\section{Works cited}

Agier, Michel (2016): Borderlands. Towards an Anthropology of the Cosmopolitan Condition. Cambridge: Polity Press.

Appiah, Kwame Anthony (2006): Cosmopolitanism. Ethics in a World of Strangers. New York: W.W. Norton.

Brennan, Timothy (1997): At Home in the World. Cosmopolitanism Now. Cambridge: Harvard University Press.

Brown, Wendy (2014): Walled States, Waning Sovereignty. Cambridge: Zone Books.

Butler, Judith (2012): “Precarious Life, Vulnerability and the Ethics of Cohabitation”. In: Journal of Speculative Philosophy, 26, 2, pp. 134-151.

Butler, Judith (2008): Frames of War: When is Life Grievable? London: Verso.

Calvin, Aaron (2014): “Author Teju Cole Talks His New Essay On Immigration, Twitter, And Censorship”. In: BuzzFeed, <https://www.buzzfeed.com/aaronc13/author-teju-cole-talkshis-new-essay-on-immigration-twitter?utm_term=.hseGNdPNL\#.vIDj9MZ9m> (last visit: 14/03/2018).

Cole, Teju (2017): Blind Spot. New York: Random House.

Cole, Teju (2016): Known and Strange Things. New York: Random House.

De Castro, Juan/Birns, Nicholas (2017): Bolaño as World Literature. London/New York: Bloomsbury.

Harvey, David (2009): Cosmopolitism and the Geographies of Freedom. New York: Columbia University Press.

Hollinger, David A. (2001): “Not Universalists, Not Pluralists: The New Cosmopolitans Find Their Own Way”. In: Constellations 8, 2 (June 2001), pp. 236-248.

Hoyos, Héctor (2016): Beyond Bolaño. The Global Latin American Novel. New York: Columbia University Press.

Kristeva, Julia (1991): Strangers to ourselves. Trans. Leon S. Roudiez. New York: Columbia University Press.

Lucas, Julian (2017): “Teju Cole: At the Border of the Visible”. In: NYRB. August 3, 2017, <https://www.nybooks.com/daily/2017/08/03/teju-cole-border-of-the-visible/> (last visit: 14/03/2018).

Müller, Gesine/Gras Miravet, Dunia (eds.) (2015): América Latina y la literatura mundial: Mercado editorial, redes globales y la invención de un continente. Madrid/Frankfurt am Main: Iberoamericana/Vervuert.

Nussbaum, Martha (1997): Cultivating Humanity. A Classical Defense of Reform in Liberal Education. Cambridge: Harvard University Press.

Robbins, Bruce/Horta, Paulo Lemos (eds.) (2017): Cosmopolitanisms. New York: New York University Press.

Saint, Lily (2018): “From a Distance: Teju Cole, World Literature, and the Limits of Connection". In: Novel, 51, 2, pp. 322-338.

Sánchez Prado, Ignacio (2018): Strategic Occidentalism. On Mexican Fiction, The Neoliberal Book Market, and The Question of World Literature. Evanston: Northwestern University Press.

Siskind, Mariano (2014): Cosmopolitan Desires. Global Modernity and World Literature in Latin America. Evanston: Northwestern University Press. 
Vermeulen, Pieter (2013): "Flights of Memory: Teju Cole's Open City and the Limits of Aesthetic Cosmopolitanism”. In: Journal of Modern Literature, 37, 1 (Fall 2013), pp. 40-57.

Werbner, Pnina (2008): Anthropology and the New Cosmopolitanism: Rooted, Feminist, and Vernacular Perspectives. Oxford: Berg. 